\title{
The Effect of Cold Work on Properties of Alloy 617
}

R. N. Wright

August 2014

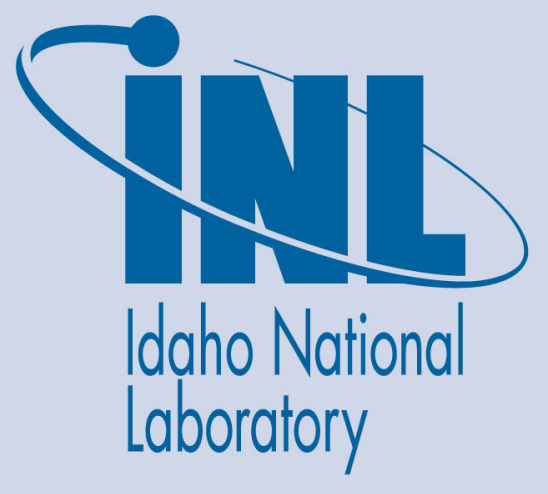

The INL is a U.S. Department of Energy National Laboratory operated by Battelle Energy Alliance 


\section{DISCLAIMER}

This information was prepared as an account of work sponsored by an agency of the U.S. Government. Neither the U.S. Government nor any agency thereof, nor any of their employees, makes any warranty, expressed or implied, or assumes any legal liability or responsibility for the accuracy, completeness, or usefulness, of any information, apparatus, product, or process disclosed, or represents that its use would not infringe privately owned rights. References herein to any specific commercial product, process, or service by trade name, trade mark, manufacturer, or otherwise, does not necessarily constitute or imply its endorsement, recommendation, or favoring by the U.S. Government or any agency thereof. The views and opinions of authors expressed herein do not necessarily state or reflect those of the U.S. Government or any agency thereof. 
INL/EXT-14-32965

Revision 0

\title{
The Effect of Cold Work on Properties of Alloy 617
}

\author{
R. N. Wright
}

August 2014

\begin{abstract}
Idaho National Laboratory
Materials Science and Engineering

Idaho Falls, Idaho 83415
\end{abstract}

http://www.inl.gov

Prepared for the

U.S. Department of Energy

Office of Nuclear Energy

Under DOE Idaho Operations Office

Contract DE-AC07-05ID14517 



\title{
Materials Science and Engineering
}

\section{The Effect of Cold Work on Properties of Alloy 617}

\author{
INL/EXT-14-32965
}

Revision 0

August 2014
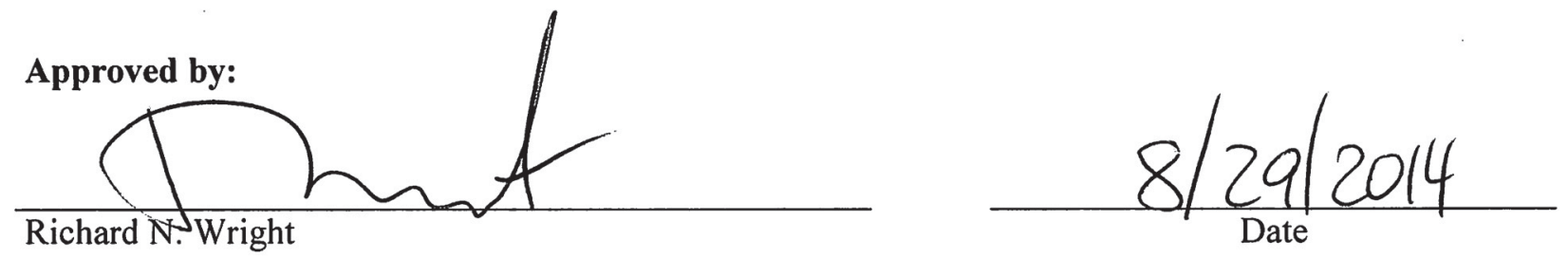


\section{ABSTRACT}

Alloy 617 is approved for non-nuclear construction in the ASME Boiler and Pressure Vessel Code Sections I and VIII, but is not currently qualified for nuclear use in ASME Code Section III. A draft Code Case was submitted in 1992 to qualify the alloy for nuclear service but efforts were stopped before the approval process was completed. ${ }^{1}$ Renewed interest in high temperature nuclear reactors has resulted in a new effort to qualify Alloy 617 for use in nuclear pressure vessels.

Code Cases are again being developed to allow use of Alloy 617 for nuclear design within the rules of the ASME Boiler and Pressure Vessel Code. In general the Code defines two temperature ranges for nuclear design with austenitic and nickel based alloys. Below $427^{\circ} \mathrm{C}\left(800^{\circ} \mathrm{F}\right)$ time dependent behavior is not considered, while above this temperature creep and creep-fatigue are considered to be the dominant life-limiting deformation modes. There is a corresponding differentiation in the treatment of the potential for effects associated with cold work. Below $427^{\circ} \mathrm{C}$ the principal issue is the relationship between the level of cold work and the propensity for stress corrosion cracking and above that temperature the primary concern is the impact of cold work on creep-rupture behavior.

In addition to the ASME Code considerations, there is a closely associated phenomenon in nickel alloys that is frequently referred to as relaxation cracking. Relaxation cracking is a mode of delayed failure usually observed in association with welds that occurs after extended periods of exposure (typically on the order of one to two years) in the temperature range where there is carbide precipitation or the ordered $\gamma^{\prime}\left(\mathrm{Ni}_{3} \mathrm{Al}\right)$ phase forms. This type of cracking is relevant here because it has been observed in cold worked nickel alloys even in the absence of weldments.

In this report the results of recent experiments and new information from several other sources have been aggregated that were not available for the 1992 draft Code Case. With implementation of the new ASME Section III Division 5 design rules that are specific for high temperature gas and sodium cooled reactors it appears that there is little chance of stress corrosion cracking and consequently no need for further consideration of cold work in the low temperature Code Case. The potential for relaxation cracking of cold worked Alloy 617 is considered in the temperature range of 500 to $750^{\circ} \mathrm{C}$ where $\gamma$ 'formation influences mechanical properties. Limits on the allowable amount of cold work at temperatures where creep-rupture is significant are also assessed with reference to both rupture experiments and the potential for recrystallization and subsequent loss of creep strength.

Cold work alters the creep rupture behavior of Alloy 617 for strains as low as 5\%. Limiting the fabrication strain to less than 5\% in components which are not solution annealed after cold work, as allowed for Alloy $800 \mathrm{H}$ in the current Section III, Subsection NH, rules is recommended. Allowing limited deformation of near-complete components is necessary to accommodate common engineering practice for operations like straightening or alignment during final assembly and installation.

For fabrication strains between 5 and $20 \%$ a post-fabrication solution heat treatment of $1150^{\circ} \mathrm{C}$ for 20 minutes $/ 25 \mathrm{~mm}$ of thickness or 10 minutes, whichever is greater, is recommended as currently required in ASME Section VIII Division 1.

It is recommended that components that will see service between 500 and $780^{\circ} \mathrm{C}$ be given a heat treatment of three hours at $980^{\circ} \mathrm{C}$ to eliminate relaxation cracking. This recommendation applies regardless of whether the material is in a cold worked, welded, or solution annealed condition.

Below the $427^{\circ} \mathrm{C}$ temperature limit for low temperature design in Section III of the Code it does not appear that cold work is of concern if the rules of Division 5 pertain. This part of the Code is specific to high temperature gas or sodium cooled reactors and stress corrosion cracking is not an issue. If Alloy 617 were to be suggested for use under the rules of Section III, Division 1, Subsection NB, the susceptibility of cold worked Alloy 617 to stress corrosion cracking in water environments would have to be addressed. 


\section{CONTENTS}

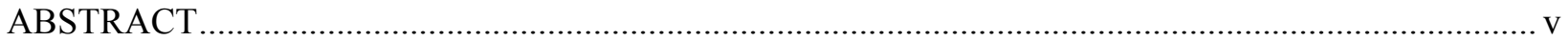

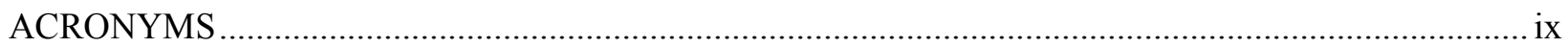

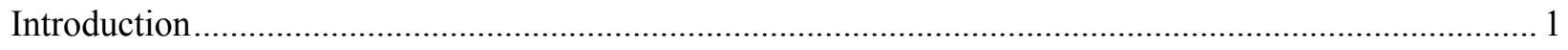

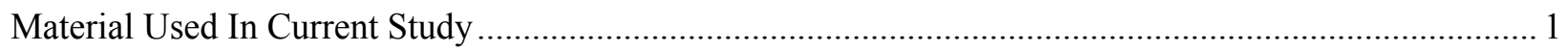

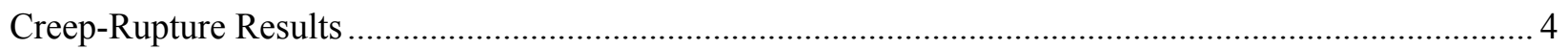

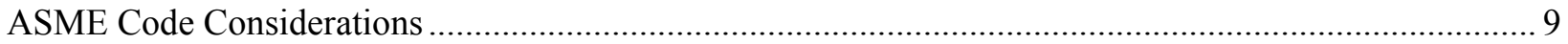

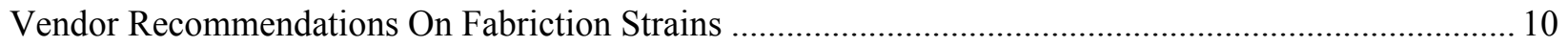

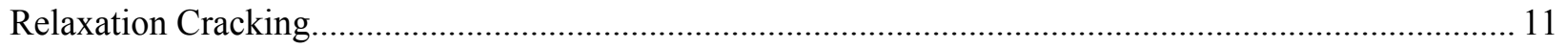

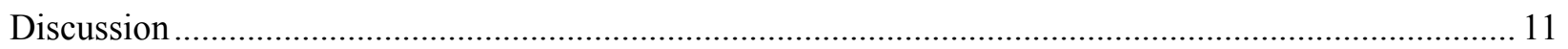

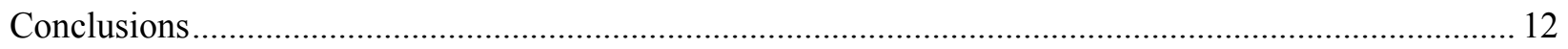

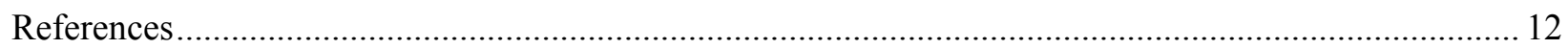

FIGURES

Figure 1. Schematic illustration of the three faces of the solution annealed Alloy 617 that were analyzed for grain size. .

Figure 2. OIM images showing the wide range of grain sizes in solution annealed Alloy 617 plate on the $\mathrm{X}, \mathrm{Y}$ and $\mathrm{Z}$ faces as defined in Figure 1.

Figure 3. Grain size distribution from OIM images on the $y$-face of the solution annealed Alloy 617 plate.

Figure 4. Creep curves for Alloy 617 in the as-received (solution annealed) condition and after $10 \%$ cold working at room temperature for a test temperature of $900^{\circ} \mathrm{C}$ and stress of 36 $\mathrm{MPa} .$.

Figure 5. Creep curves for Alloy 617 in the as-received (solution annealed) condition and after $10 \%$ cold working at room temperature for a test temperature of $1000^{\circ} \mathrm{C}$ and stress of $13 \mathrm{MPa}$.

Figure 6. Creep-rupture curves for Alloy 617 in the solution annealed, statically aged and cold worked condition at $850^{\circ} \mathrm{C}$ and a stress of $70 \mathrm{MPa}$ from Chomette et al. ${ }^{2}$

Figure 7. Creep curves for interrupted tests at $850^{\circ} \mathrm{C}$ and $36 \mathrm{MPa}$ on solution annealed Alloy 617 and specimens pre-strained to three different levels of cold work from Cook. ${ }^{3}$......

Figure 8. Creep-rupture curves for Alloy 617 in the solution annealed, statically aged and cold worked condition at $950^{\circ} \mathrm{C}$ and a stress of $30 \mathrm{MPa}$ from Chomette et al. ${ }^{2}$

Figure 9. Larson-Miller plot for creep-rupture of solution annealed plate material tested in the current R\&D program and cold worked material. 
Figure 10. OIM images of (a) region near the fracture surface of a specimen tested to rupture in creep at a temperature of $900^{\circ} \mathrm{C}$ and stress of $36 \mathrm{MPa}$ and (b) sample recrystallized at $1000^{\circ} \mathrm{C}$ after bulk deformation to $50 \%$ by rolling.

Figure 11. ASME Section III Subsection NH allowable temperature limits for short-time

exposure of material allowed materials cold worked more than 5 and less than $20 \%$.

Figure 12. Requirements for post-fabrication heat treatment of cold worked alloys, including Alloy 617, in Table UNF-79 of Section VIII Division 1. 10

\section{TABLES}

Table 1. Chemical Analysis of ThyssenKrupp VDM, heat number 314626. . 2 


\section{ACRONYMS}

$\begin{array}{ll}\text { ASME } & \text { American Society of Mechanical Engineers } \\ \text { BPVC } & \text { Boiler and Pressure Vessel Code } \\ \text { DOE } & \text { Department of Energy } \\ \text { HTGR } & \text { High-Temperature Gas Reactor } \\ \text { INL } & \text { Idaho National Laboratory } \\ \text { NE } & \text { DOE Office of Nuclear Energy } \\ \text { NRC } & \text { Nuclear Regulatory Commission } \\ \text { ORNL } & \text { Oak Ridge National Laboratory } \\ \text { OIM } & \text { Orientation Imaging Microscopy } \\ \text { PWHT } & \text { Post Weld Heat Treatment } \\ \text { QA } & \text { Quality Assurance } \\ \text { R\&D } & \text { Research and Development } \\ \text { VHTR } & \text { Very High-Temperature Reactor }\end{array}$




\section{The Effect of Cold Work on Properties of Alloy 617 INTRODUCTION}

Alloy 617 is approved for non-nuclear construction in the ASME Boiler and Pressure Vessel Code Sections I and VIII, but is not currently qualified for nuclear use in ASME Code Section III. A draft Code Case was submitted in 1992 to qualify the alloy for nuclear service but efforts were stopped before the approval process was completed. ${ }^{1}$ Renewed interest in high temperature nuclear reactors has resulted in a new effort to qualify Alloy 617 for use in nuclear pressure vessels.

The mechanical and physical properties of Alloy 617 were extensively characterized for the VHTR programs in the 1980's and incorporated into the 1992 draft Code Case. Recently, the properties of modern heats of the alloy that incorporate an additional processing step, electro-slag re-melting, have been characterized both to confirm that the properties of contemporary material are consistent with those in the historical record and to increase the available database. A number of potential issues that were identified as requiring further consideration prior to the withdrawal of the 1992 Code Case are also being re-examined in the current $R \& D$ program.

Code Cases are again being developed to allow use of Alloy 617 for nuclear design within the rules of the ASME Boiler and Pressure Vessel Code. In general the Code defines two temperature ranges for nuclear design with austenitic and nickel based alloys. Below $427^{\circ} \mathrm{C}\left(800^{\circ} \mathrm{F}\right)$ time dependent behavior is not considered, while above this temperature creep and creep-fatigue are considered to be the dominant life-limiting deformation modes. There is a corresponding differentiation in the treatment of the potential for effects associated with cold work. Below $427^{\circ} \mathrm{C}$ the principal issue is the relationship between the level of cold work and the propensity for stress corrosion cracking and above that temperature the primary concern is the impact of cold work on creep-rupture behavior.

Austenitic and nickel based alloys are also susceptible to delayed cracking during service in the temperature range where the materials are strengthened by precipitation of carbides or $\gamma^{\prime}$ formation. This phenomenon is frequently referred to as relaxation cracking because it is usually associated with strains accompanying relaxation of residual stresses related to welds. This type of cracking needs to be considered here because it has also been observed in cold worked nickel alloys even in the absence of weldments.

In this report the results of recent experiments and new information from several other sources have been aggregated that were not available for the 1992 draft Code Case. With implementation of the new ASME Section III Division 5 design rules that are specific for high temperature gas and sodium cooled reactors it appears that there is little chance of stress corrosion cracking and consequently no need for further consideration of cold work in the low temperature Code Case. The potential for relaxation cracking of cold worked Alloy 617 in the temperature range of 500 to $750^{\circ} \mathrm{C}$ where formation influences mechanical properties is discussed here. Limits on the allowable amount of cold work at temperatures where creep-rupture is significant will also be assessed with reference to both rupture experiments and the potential for recrystallization and subsequent loss of creep strength.

\section{MATERIAL USED IN CURRENT STUDY}

Alloy 617 is strengthened by solid solution hardening provided by the alloy elements chromium, cobalt and molybdenum as well as by intra- and inter-granular carbide precipitates. High temperature oxidation resistance is derived from the high nickel and chromium content. The solution annealed material tested in the current experiments was from $35 \mathrm{~mm}$ thick hot rolled plate that was manufactured by ThyssenKrupp VDM, Inc. The alloy was prepared using induction melting, followed by electro-slag 
re-melting prior to casting the ingot. Chemistry of the plate (heat \# number 314626) reported on here is given in Table 1.

Table 1. Chemical Analysis of ThyssenKrupp VDM, heat number 314626.

\begin{tabular}{|l|l|l|l|l|l|l|l|l|l|l|l|l|l|}
\hline $\mathrm{C}$ & $\mathrm{Mn}$ & $\mathrm{Si}$ & $\mathrm{P}$ & $\mathrm{S}$ & $\mathrm{Cr}$ & $\mathrm{Ni}$ & $\mathrm{Co}$ & $\mathrm{Mo}$ & $\mathrm{Ti}$ & $\mathrm{Al}$ & $\mathrm{B}$ & $\mathrm{Cu}$ & $\mathrm{Fe}$ \\
\hline 0.05 & 0.1 & 0.1 & 0.005 & $<0.002$ & 22.2 & 54.1 & 11.6 & 8.6 & 0.4 & 1.1 & $<0.001$ & 0.04 & 1.6 \\
\hline
\end{tabular}

Thermomechanical processing, i.e. hot rolling and solution anneal, has the potential to develop different microstructures in the three orthogonal directions in the plate. Therefore, samples were cut from the plate with orientations of each of the three faces shown in Fig. 1. The samples were mechanically polished ( $3 \mu \mathrm{m} \mathrm{Al}_{2} \mathrm{O}_{3}$ final polishing step) and then electropolished for $\sim 7$ seconds in an electrolyte of ethanol- $10 \%$ ethylene glycol monobutyl ether- $10 \%$ water- $6.7 \%$ perchloric acid at $17^{\circ} \mathrm{C}$ and 14 volts in the Stuers LectroPol-5 to remove artifacts produced by mechanical polishing. Orientation Imaging Microscopy (OIM) was performed on all three faces with the labeling convention shown in Figure 1.

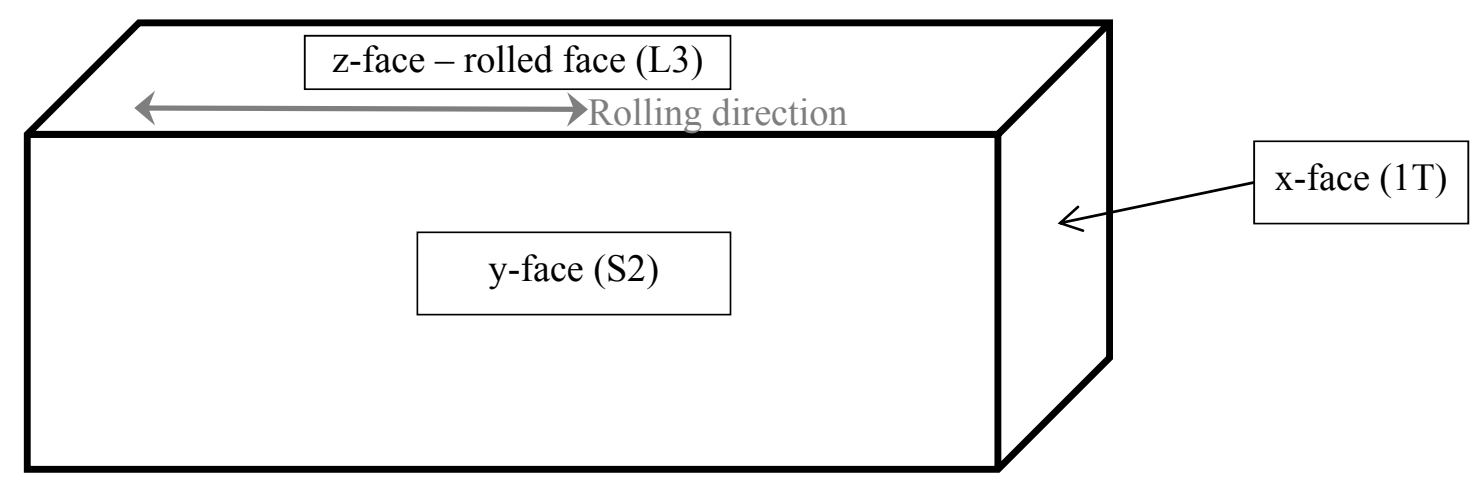

Figure 1. Schematic illustration of the three faces of the solution annealed Alloy 617 that were analyzed for grain size.

Three areas on the $\mathrm{x}$-face and $\mathrm{z}$-face were analyzed for grain size while two areas on the $\mathrm{y}$-face were analyzed. Each area was approximately $1.3 \mathrm{~mm}$ by $3 \mathrm{~mm}$ and a step size of 2 microns was used for OIM data collection to produce a dataset for each area containing over 1 million points. Twin boundaries were removed from the calculations of grain size. This included not only $\Sigma 3$ twins but also higher order twins, as well, e.g. $\Sigma 9$ and $\Sigma 27$. The fraction of these higher order twins is much lower than the fraction of the $\Sigma 3$ twin boundaries and their removal did not significantly affect the calculated grain size. Grains touching the edge of the analysis area were also excluded from the grain size calculation. Only high angle grain boundaries $\left(>15^{\circ}\right.$ mis-orientation) were included in the grain size determination.

The minimum grain size in the analysis of the OIM data was set to approximately 10 microns in diameter (grains smaller than 10 microns were not included in the average grain size calculation). OIM images of each face are shown in Figure 2 and a plot of the range of observed grain sizes for the $\mathrm{Y}$ face is shown in Figure 3. It is clear that there is a population of much smaller grains even in the solution annealed material. Observation of these very small grains in the solution annealed as-received plate is relevant because there are reports in the literature that the extensive deformation near the fracture surface of failed creep-rupture specimens can result in recrystallization even for solution annealed material. ${ }^{2}$ One plausible effect of cold working Alloy 617 prior to creep testing would be bulk recrystallization and subsequently increased creep rates resulting from a change in creep mechanism associated with fine grained material. The presence of bands of fine grains in the solution annealed material could complicate post-test analysis of the microstructures; the possible contribution of fine grains to the rupture life is also already incorporated at least in part in measurements of the solution annealed material. 


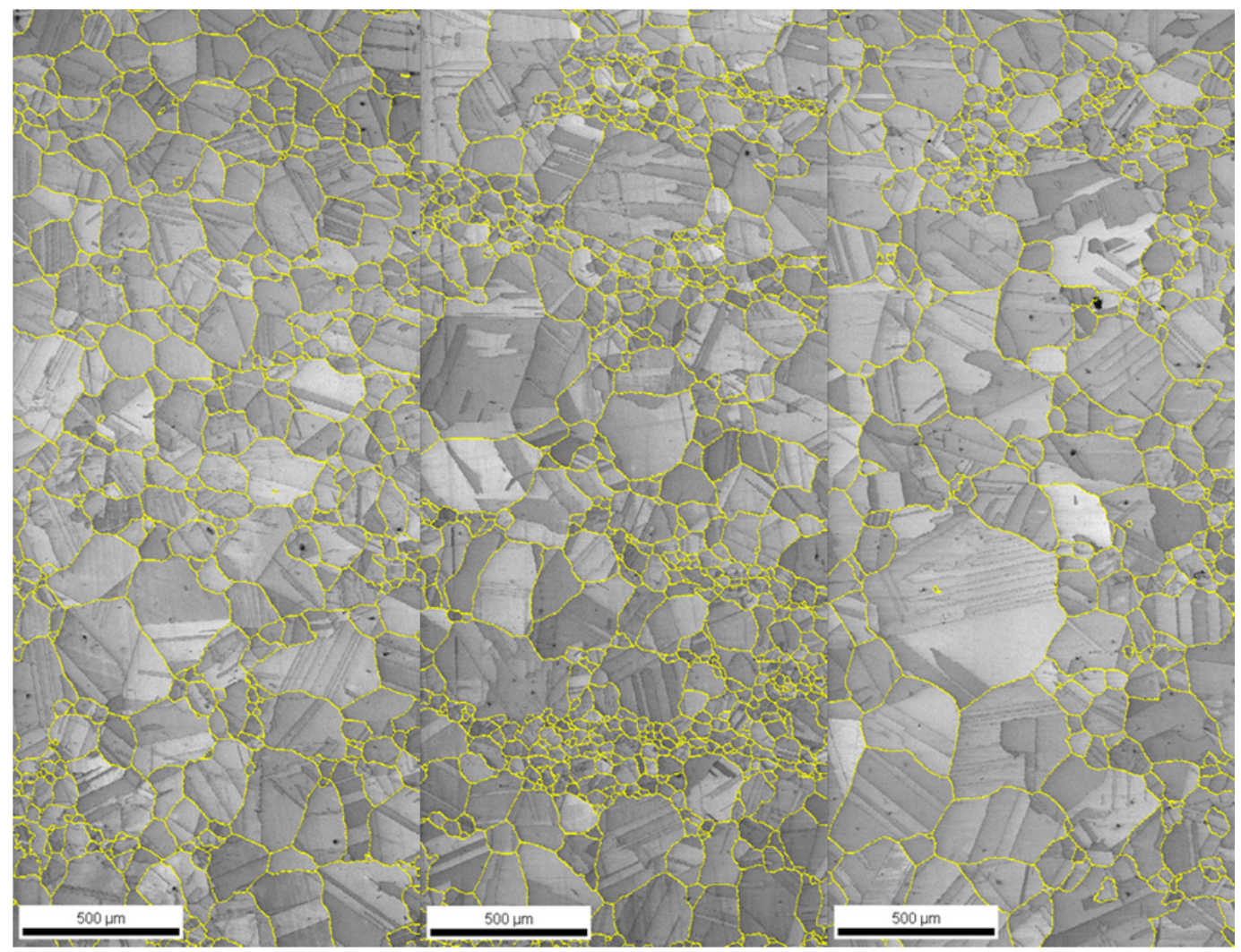

Figure 2. OIM images showing the wide range of grain sizes in solution annealed Alloy 617 plate on the $\mathrm{X}, \mathrm{Y}$ and $\mathrm{Z}$ faces as defined in Figure 1 .

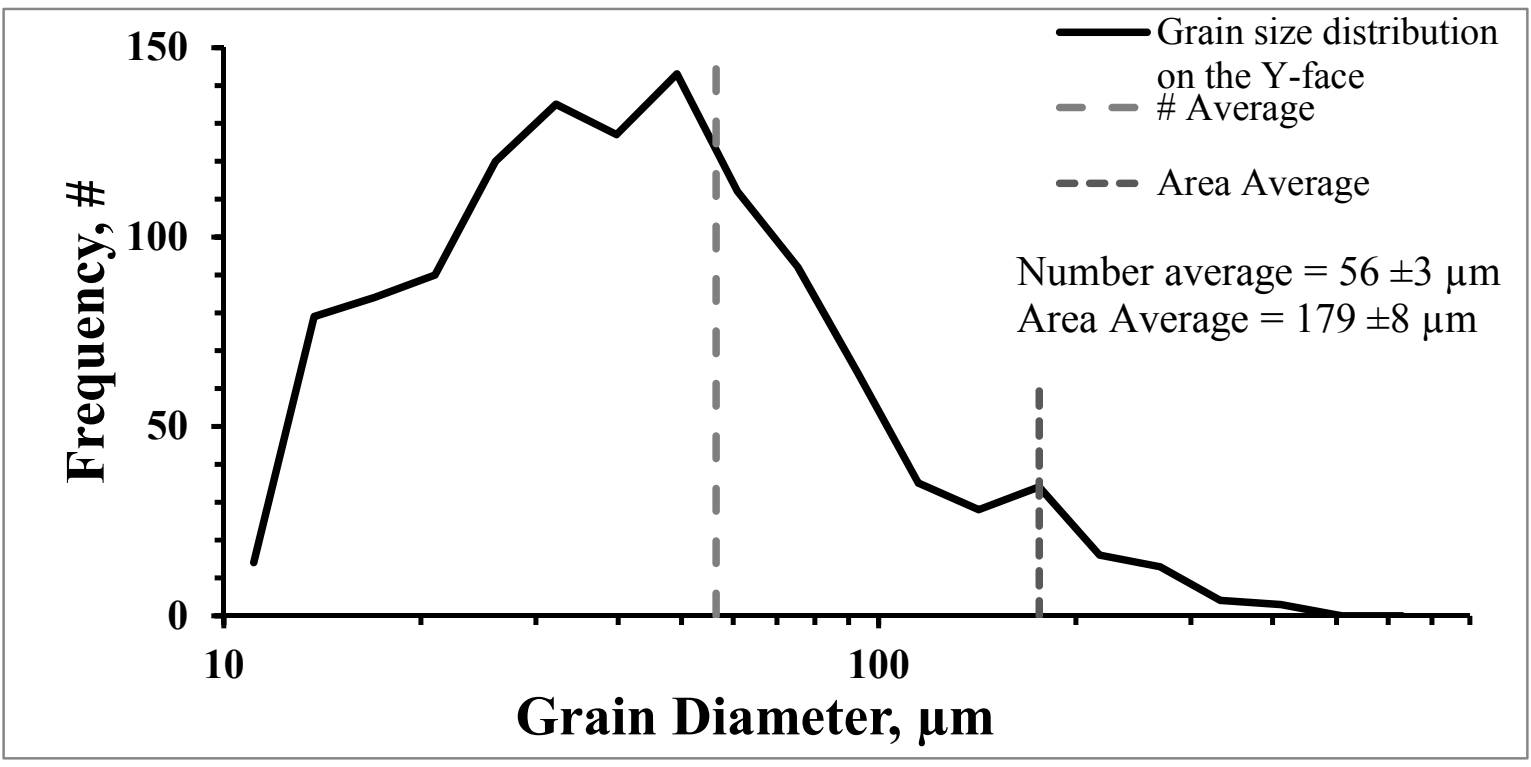

Figure 3. Grain size distribution from OIM images on the y-face of the solution annealed Alloy 617 plate. 


\section{CREEP-RUPTURE RESULTS}

The most significant potential effect of cold work on Alloy 617 properties at VHTR heat exchanger inlet temperatures is reduced creep-rupture life. Several reports on this effect have been published with a range of temperatures and pre-strain levels. ${ }^{2,3}$ Additional rupture experiments have been carried out as part of the current $R \& D$ program to examine a more comprehensive range of test conditions and to examine the role of recrystallization with respect to changes in creep rates and rupture behavior resulting from cold work. Creep curves for two tests that have gone to rupture in the current program are shown in Figure 4 and Figure 5. For these tests the specimen was strained in tension at room temperature to a total strain of $10 \%$ prior to creep testing. At $900^{\circ} \mathrm{C}$ the creep rate, strain to failure and the time to rupture are significantly reduced in the cold worked material with respect to a comparable creep-rupture test on solution annealed material. Creep testing the cold worked material at $1000^{\circ} \mathrm{C}$ showed increased creep rate compared to solution annealed material, however, the strain and time to failure were both reduced as seen at the lower temperature.

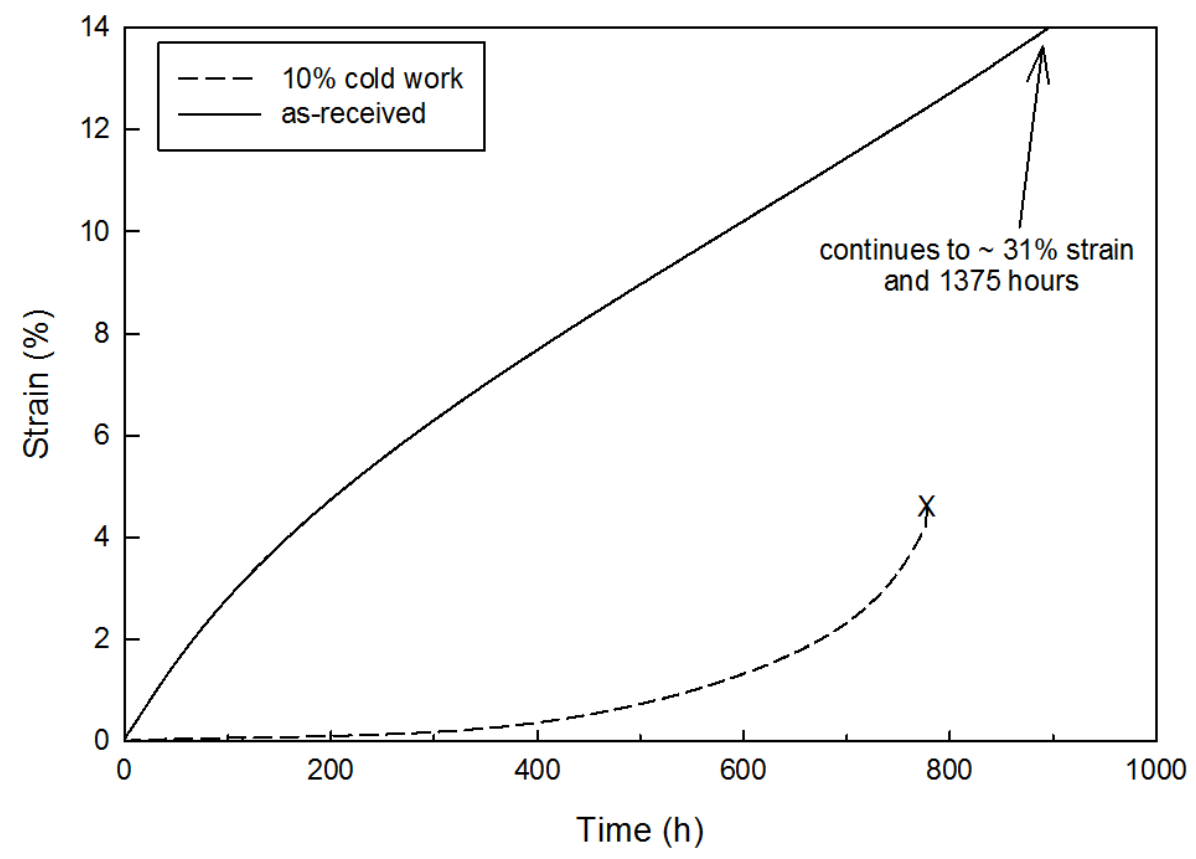

Figure 4. Creep curves for Alloy 617 in the as-received (solution annealed) condition and after $10 \%$ cold working at room temperature for a test temperature of $900^{\circ} \mathrm{C}$ and stress of $36 \mathrm{MPa}$. 


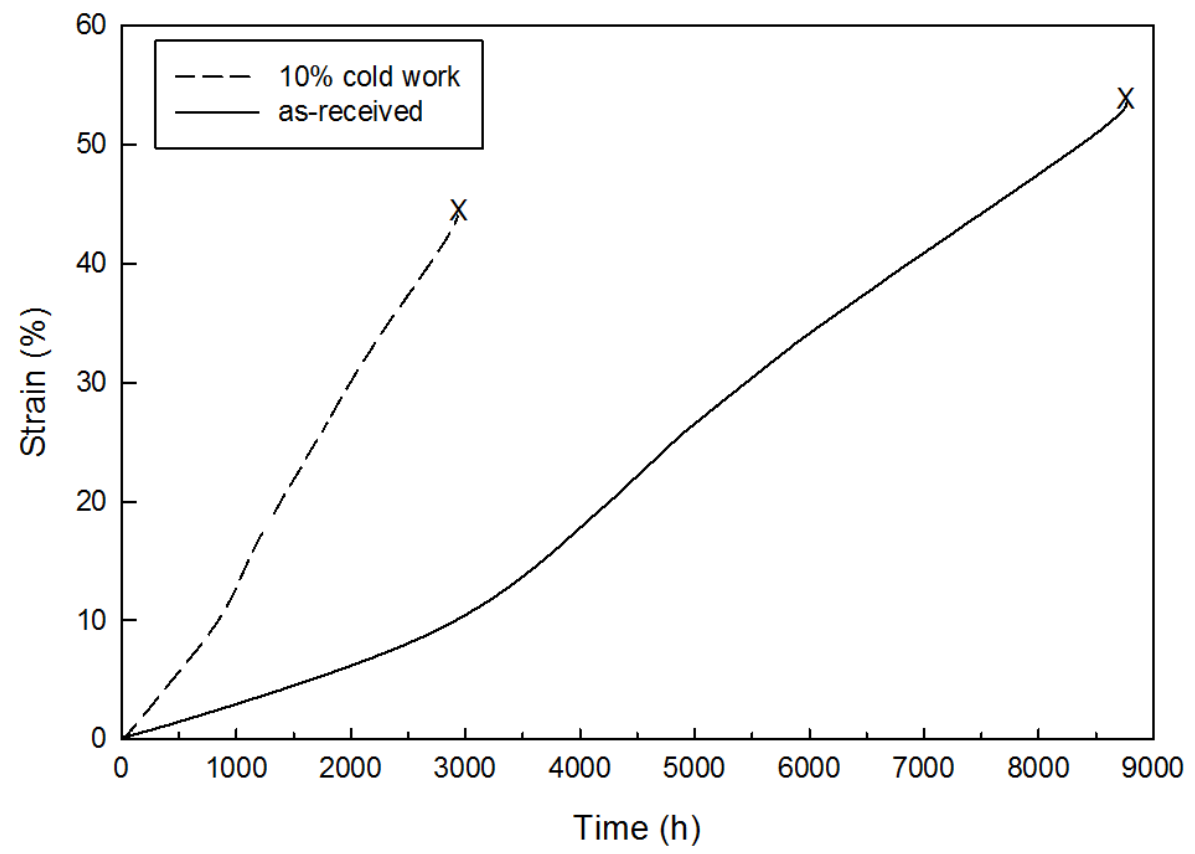

Figure 5. Creep curves for Alloy 617 in the as-received (solution annealed) condition and after 10\% cold working at room temperature for a test temperature of $1000^{\circ} \mathrm{C}$ and stress of $13 \mathrm{MPa}$.

Results of creep experiments at $850^{\circ} \mathrm{C}$ reported in the literature are shown for several cold worked Alloy 617 specimens in Figure 6 and Figure $7 .^{2}$ The total tensile pre-strain for the creep-rupture test shown in Figure 6 was 20\%, however, the specimen exhibited similar qualitative behavior as the 10\% cold work specimen tested in the current program. The creep rate, time and strain to failure are all reduced compared to solution annealed material as a result of the prior cold work. It can be seen from Figure 7 for creep tests that were interrupted after 3000 hours that the amount of cold work has little influence on the creep rate over the range of 5 to $20 \%$ and the rates are much reduced compared to solution annealed material.

Figure 8 shows rupture curves from the literature for Alloy 617 in the solution annealed, aged and $20 \%$ cold worked condition for testing at $950^{\circ} \mathrm{C}$ and a stress of $30 \mathrm{MPa}^{3}$ The creep-rupture behavior of cold worked material at this temperature is qualitatively similar to that shown in the current work for $10 \%$ pre-strain tested at $1000^{\circ} \mathrm{C}$. The creep rate is significantly increased compared to solution annealed material and the time and strain to rupture are significantly reduced.

Several additional specimens are under test in the current program to examine the influence of additional test temperatures and levels of pre-strain on rupture life. From the available results it is clear that cold work can reduce the creep rate at the lower end of temperatures of interest to VHTR heat exchangers, while at higher temperatures the creep rate is accelerated. The time to rupture is reduced for all conditions of cold work strain and temperature that have been examined.

A common method of presenting creep-rupture data normalized for time, temperature and stress is the Larson-Miller formulation. A Larson-Miller plot for creep-rupture of cold worked material from this $R \& D$ program and data reported in the literature is shown along with solution annealed plate material tested in the current R\&D program in Figure 9. While it is clear from the individual tests that the time to rupture is decreased by prior cold work, there is only a small indication in the Larson-Miller plot that the rupture properties are degraded at high temperature. This may in part be a reflection of the log-log nature of the plot diminishing the apparent influence of cold work. 


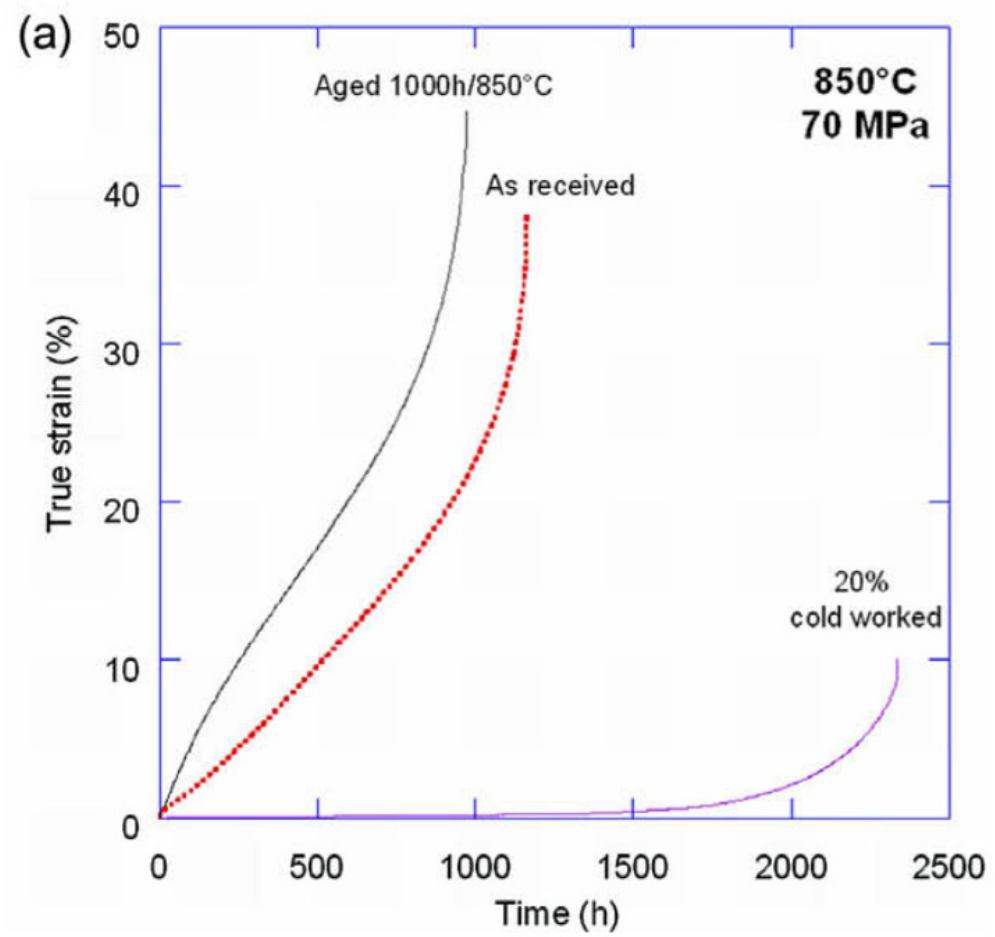

Figure 6. Creep-rupture curves for Alloy 617 in the solution annealed, statically aged and cold worked condition at $850^{\circ} \mathrm{C}$ and a stress of $70 \mathrm{MPa}$ from Chomette et al. ${ }^{2}$

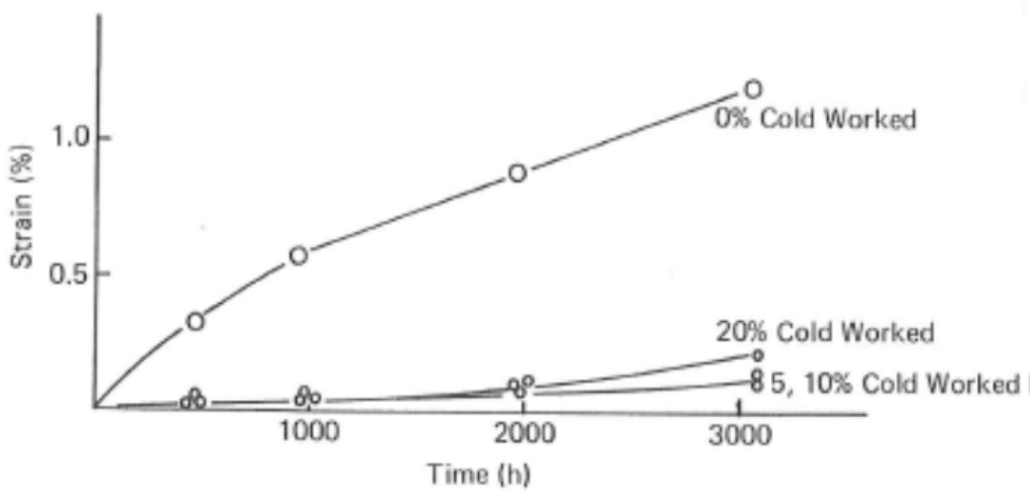

(a) Creep Results, $850^{\circ} \mathrm{C}, 36 \mathrm{MPa}$, Helium

Figure 7. Creep curves for interrupted tests at $850^{\circ} \mathrm{C}$ and $36 \mathrm{MPa}$ on solution annealed Alloy 617 and specimens pre-strained to three different levels of cold work from Cook. ${ }^{3}$ 


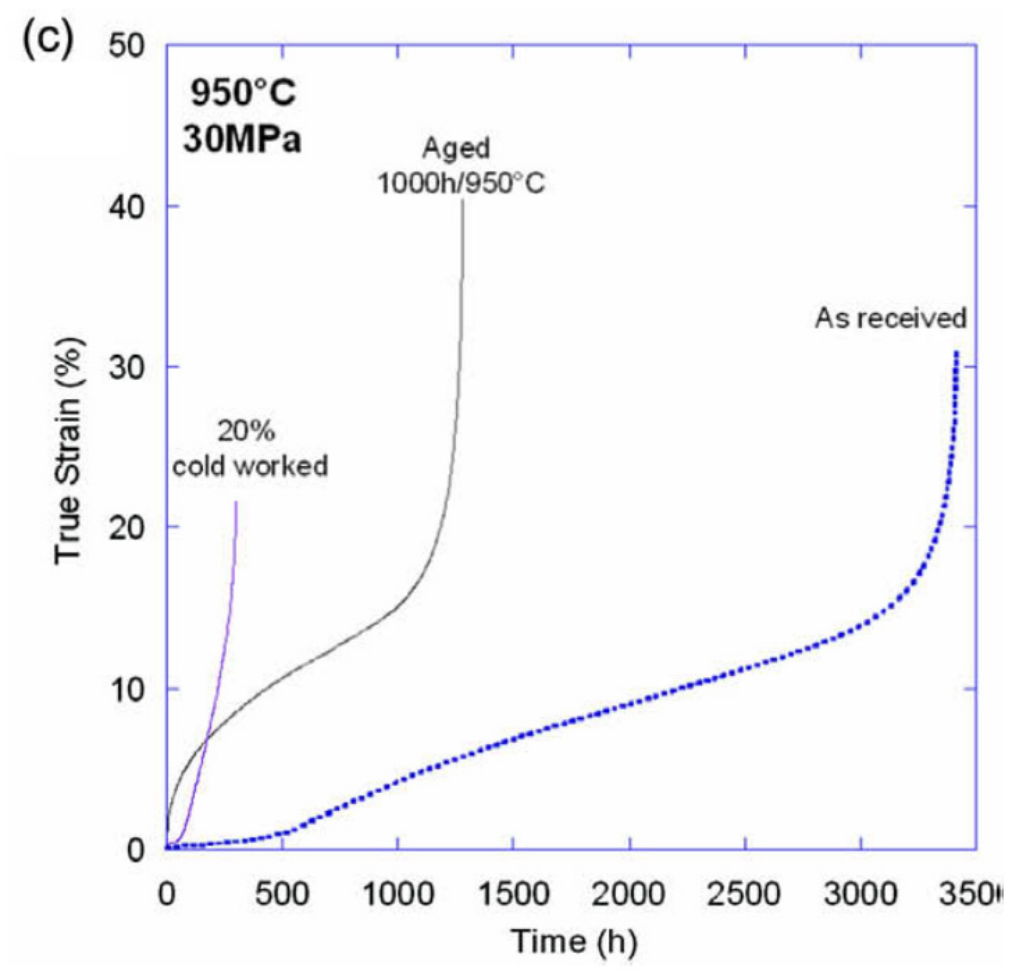

Figure 8. Creep-rupture curves for Alloy 617 in the solution annealed, statically aged and cold worked condition at $950^{\circ} \mathrm{C}$ and a stress of $30 \mathrm{MPa}$ from Chomette et al. ${ }^{2}$

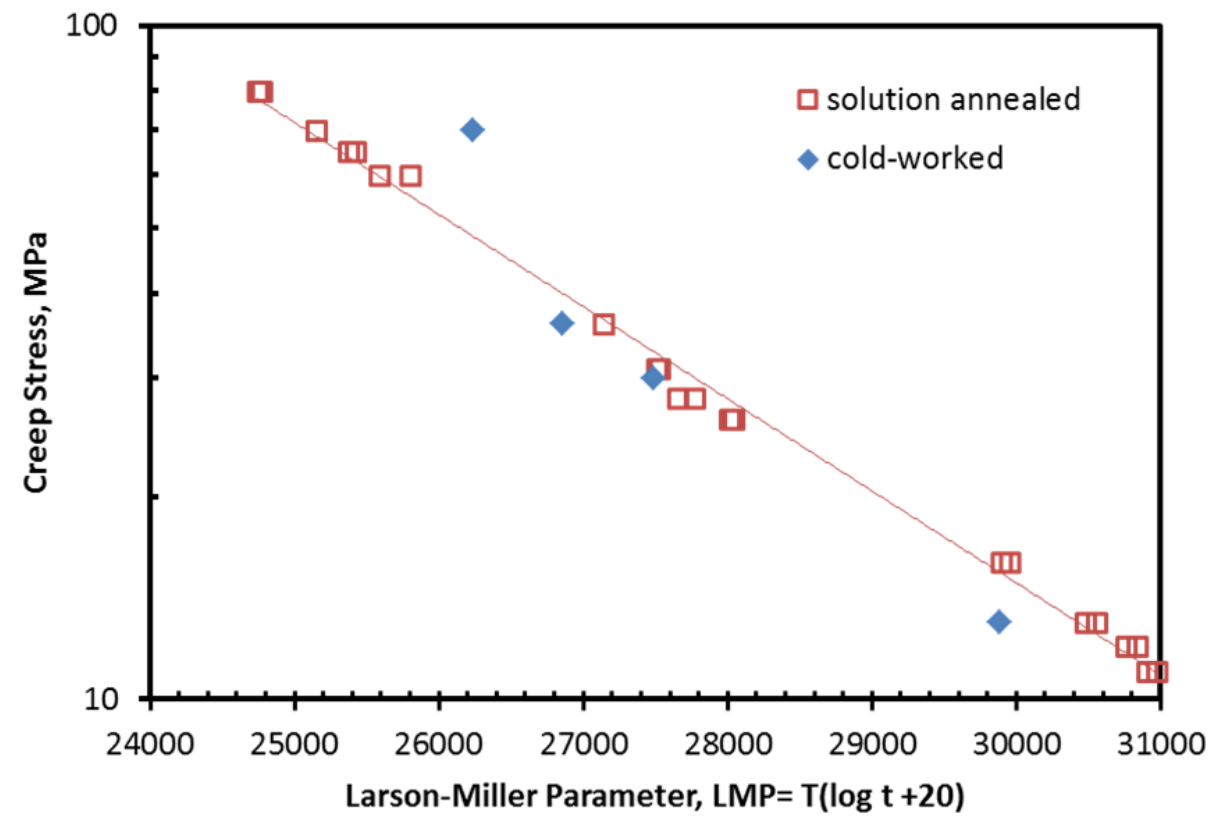

Figure 9. Larson-Miller plot for creep-rupture of solution annealed plate material tested in the current $\mathrm{R} \& \mathrm{D}$ program and cold worked material. 
Chomette et al., show optical micrographs of cross sections through ruptured specimens of solution annealed and aged material, but not for the specimens cold worked prior to creep-rupture testing. ${ }^{2}$ They examined regions near and far away from the fracture. For both the annealed and aged material they show evidence of recrystallization at both locations in the specimen; however, they claim extensive recrystallization only near the fracture surface. Their rationalization of observations from optical microscopy involves a series of steps including flow localization, dissolution of carbides, recrystallization and re-precipitation of carbides. For the purposes of this discussion the most significant observation is that extensive recrystallization appears to be driven by localized deformation associated with necking in creep-rupture specimens even in the absence of bulk cold working prior to creep testing.

Recrystallization of Alloy 617 is very difficult to characterize using optical metallography. Unpublished collaborative research between the current R\&D program and Boise State University characterized recrystallization of Alloy 617 that had been cold rolled to $50 \%$ reduction. It was found that conventional polishing and chemical etching revealed only the carbides associated with solution annealed grain boundaries even in material that hardness measurements indicated was fully recrystallized. It was determined that electropolishing and etching could resolve fine recrystallized grains; however, the most certain method for showing recrystallization was using OIM. Figure 10(a) shows an OIM image from near the fracture surface from the $10 \%$ cold work sample tested to rupture at $900^{\circ} \mathrm{C}$ at a stress of $36 \mathrm{MPa}$. A fully recrystallized bulk sample from the $50 \%$ cold rolled material annealed for one hour at $1000^{\circ} \mathrm{C}$ is shown in Figure 10(b).

It is obvious from visual comparison of the images that bulk recrystallization did not occur under these rupture conditions. The total strain to rupture for this sample was approximately $5 \%$, whereas the strain to failure in the sample for which Chomette et al., report recrystallization near the fracture was on the order of $40 \% .{ }^{2}$ This suggests that dynamic recrystallization occurs during creep-rupture testing due to large localized strain even in the absence of cold work. Bulk recrystallization does not occur in cold worked material for all rupture conditions. These combined results suggest that recrystallization to a fine grain size and concomitant reduction in creep properties is probably not a dominant mechanism for the generally observed cold work effect. Efforts to confirm this observation are hindered by the uncertainty of identifying recrystallization in some of the literature where only optical micrographs are shown.

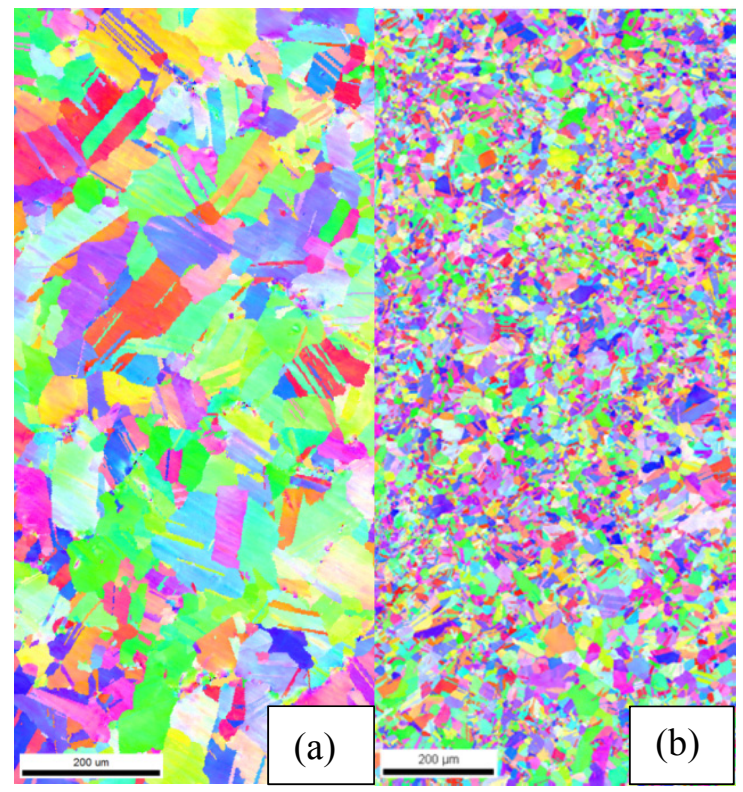

Figure 10. OIM images of (a) region near the fracture surface of a specimen tested to rupture in creep at a temperature of $900^{\circ} \mathrm{C}$ and stress of $36 \mathrm{MPa}$ and (b) sample recrystallized at $1000^{\circ} \mathrm{C}$ after bulk deformation to $50 \%$ by rolling. 


\section{ASME CODE CONSIDERATIONS}

Section III Subsection NH allows use of only three austenitic structural materials, Type 304 and 316 stainless steel, and Alloy $800 \mathrm{H} .{ }^{4}$ Subsection $\mathrm{NH}$ does not require post-fabrication heat treatment for materials that have experienced strains of less than $5 \%$. For NH qualified materials allowable temperature limits have been determined for short-time exposure of material cold worked more than 5 and less than $20 \%$ for which heat treatment is not required. These limits are given in Figure NH-4212-1 in the Code and the figure is reproduced here as Figure 11. For exposure greater than these time/temperature limits the material is required to be heat treated to the solution annealing conditions specified in the appropriate standard for solution annealed material. For Alloy 617 this temperature is $1150^{\circ} \mathrm{C}$.

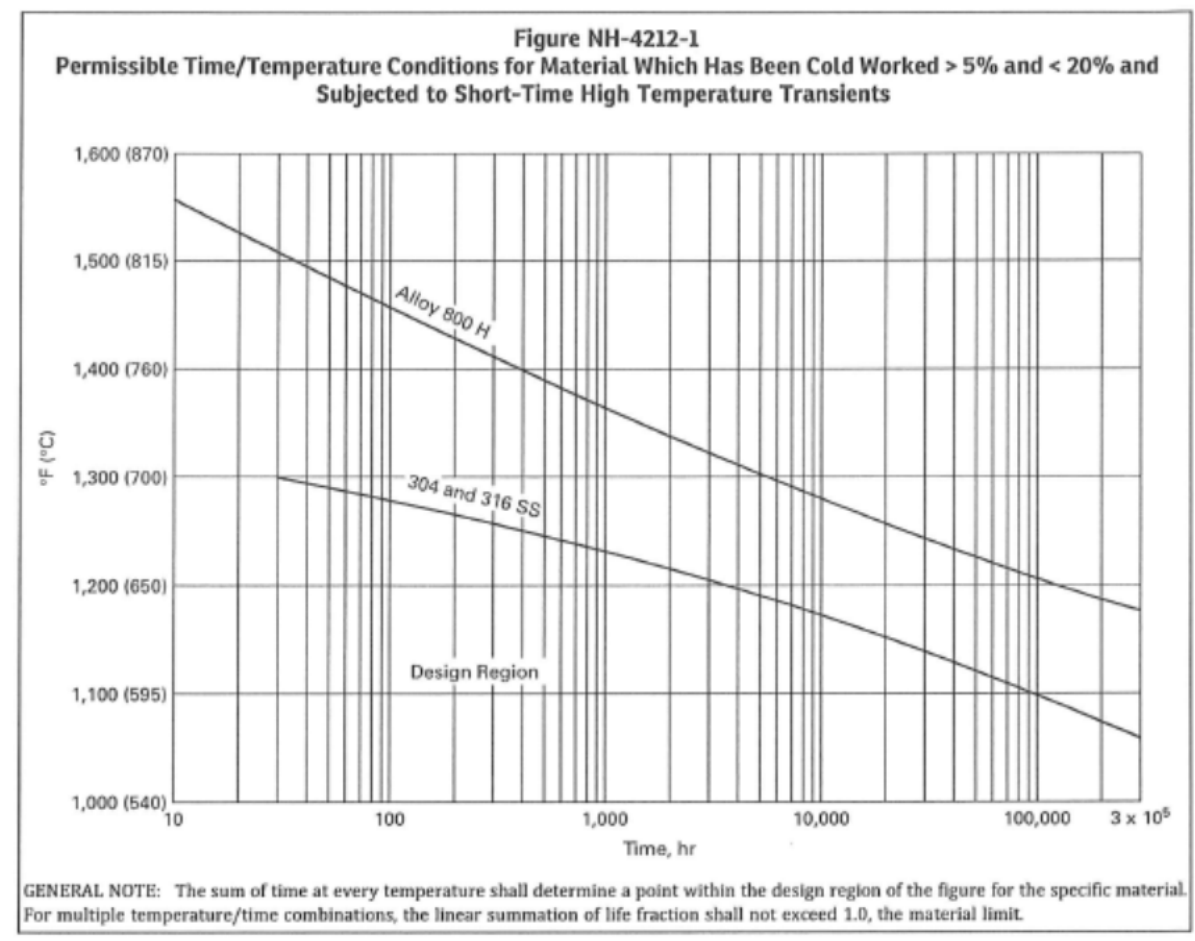

Figure 11. ASME Section III Subsection NH allowable temperature limits for short-time exposure of material allowed materials cold worked more than 5 and less than $20 \%$.

It should be noted that Alloy 617 is allowed for design of non-nuclear pressure vessels in Section VIII Division 1 of the ASME Code. ${ }^{5}$ Requirements for post-fabrication heat treatment of cold worked alloys, including Alloy 617, are given in Table UNF-79 of Section VIII Division 1 (reproduced here as Figure 12). The limits for permissible strain shown in the table for Alloy 617 are $15 \%$ in the design temperature range 540 to $675^{\circ} \mathrm{C}$ and $10 \%$ in the temperature range exceeding $675^{\circ} \mathrm{C}$. If these strain limits are exceeded for cold working, defined as "the finishing-forming temperature is below the minimum heattreating temperature given in Table UNF-79", a post-fabrication solution treatment is required. This heat treatment is specified as heating to the temperature given in the table $\left(1150^{\circ} \mathrm{C}\right.$ for Alloy 617$)$ for 20 minutes $/ 25 \mathrm{~mm}$ of thickness or 10 minutes, whichever is greater. 


\begin{tabular}{|c|c|c|c|c|c|c|c|}
\hline \multirow[b]{4}{*}{ Grade } & \multicolumn{7}{|c|}{$\begin{array}{c}\text { Table UNF-79 } \\
\text { Postfabrication Strain Limits and Required Heat Treatment }\end{array}$} \\
\hline & \multirow{3}{*}{$\begin{array}{l}\text { UNS } \\
\text { Number }\end{array}$} & \multicolumn{3}{|c|}{ Limitation in Lower Temperature Range } & \multicolumn{2}{|c|}{$\begin{array}{l}\text { Limitations in Higher } \\
\text { Temperature Range }\end{array}$} & \multirow{3}{*}{$\begin{array}{l}\text { Minimum Heat Treatment } \\
\text { Temperature, }{ }^{\circ}\left({ }^{\circ} \mathrm{C}\right] \text {, When } \\
\text { Design Temperature and } \\
\text { Forming Strain Limits Are } \\
\text { Exceeded [Note [1]] }\end{array}$} \\
\hline & & \multicolumn{2}{|c|}{ For Design Temperature, "F ("C) } & \multirow{2}{*}{$\begin{array}{l}\text { And Forming } \\
\text { Strains } \\
\text { Exceeding \% }\end{array}$} & \multirow{2}{*}{$\begin{array}{l}\text { For Design } \\
\text { Tempera- } \\
\text { ture, }{ }^{\circ} \mathrm{F}\left({ }^{\circ} \mathrm{C}\right) \text {. } \\
\text { Exceeding }\end{array}$} & \multirow{2}{*}{$\begin{array}{l}\text { And Forming } \\
\text { Strain } \\
\text { Exceeding \% }\end{array}$} & \\
\hline & & Exceeding & Equal To & & & & \\
\hline .. & N06230 & $1,100(595)$ & $1,400(760)$ & 15 & $1,400(760)$ & 10 & $2,200(1205)$ \\
\hline 600 & N06600 & $1,075(580)$ & $1,200[650]$ & 20 & $1,200(650)$ & 10 & $1,900\left(\begin{array}{ll}1 & 040\end{array}\right)$ \\
\hline 617 & N06617 & $1,000(540)$ & $1,250[675]$ & 15 & $1,250(675)$ & 10 & $2,100(1 \quad 150)$ \\
\hline 800 & NoBBo0 & $1,100(595)$ & $1,250[675]$ & 15 & $1,250(675)$ & 10 & $1,800[980)$ \\
\hline $800 \mathrm{H}$ & N08810 & $1.100(595)$ & $1,250[675]$ & 15 & $1,250[675]$ & 10 & $2,050(1 \quad 120)$ \\
\hline$\ldots$ & N08B11 & $1,100(595)$ & $1,250[675]$ & 15 & $1,250[675]$ & 10 & $2,050(1120)$ \\
\hline \multicolumn{8}{|c|}{$\begin{array}{l}\text { GENERAL NOTES: } \\
\text { (a) The limits shown are for cylinders formed from plates, spherical or dished heads formed from plate, and tube and pipe bends. } \\
\text { (b) When the forming strains cannot be calculated as shown in UNF-79(a), the forming strain limits shall be half those tabulated in this Table } \\
\text { [see UNF-79(b)]. }\end{array}$} \\
\hline \multicolumn{8}{|c|}{$\begin{array}{l}\text { NOTE: } \\
\text { (1) Rate of cooling from beat-treatment temperature is not subject to specific control limits. }\end{array}$} \\
\hline
\end{tabular}

Figure 12. Requirements for post-fabrication heat treatment of cold worked alloys, including Alloy 617, in Table UNF-79 of Section VIII Division 1.

It has not been possible to recover the background for Figure NH-4212-1, however, it is reasonable to assume that the limits on Alloy 617 would be similar to those for Alloy $800 \mathrm{H}$. For the desired 100,000 hour life that is currently being considered by the ASME Alloy 617 Code Qualification Task Group for desired heat exchanger design temperature up to $950^{\circ} \mathrm{C}$, this material would be limited to $5 \%$ or less cold work without post-fabrication solution anneal. In contrast, under the Section VIII rules it appears that a forming strain of $10 \%$ would be allowed without post-fabrication heat treatment.

In the Subsection to the Introduction of the 1992 draft Code Case entitled "Aspects of Construction Covered by These Rules" it is explicitly stated that "cold worked material is excluded". As noted above in the current Section III Subsection NH rules there are time/temperature limits on allowable cold work between 5 and $20 \%$, however, it appears up to $5 \%$ cold work could be allowed for any temperature of exposure. It is not clear in Section III Subsection NH how the 5\% value was determined; it is noted that cold work incidental to fabrication, e.g., straightening components for installation, is allowed on solution annealed material without further heat treatment. It is not clear if the $1992 \mathrm{draft}$ code Case intended to allow this amount of incidental cold work.

\section{VENDOR RECOMMENDATIONS ON FABRICTION STRAINS}

Special Metals, the original developer of Alloy 617 (known as Inconel 617 while under patent), as well as Haynes International and VDM all caution against imposing small amounts of cold work, generally less than $10 \%$ to any of the solid solution nickel based alloys. ${ }^{6-9}$ Depending on the particular alloy, this limited amount of cold work can result in abnormal grain growth during prolonged exposure to elevated service temperatures. In a study specific to Alloy 617 Special Metals examined the effect of abnormal grain growth on low cycle fatigue properties and found degraded properties. ${ }^{6}$ Haynes International presents data in their fabrication guide for Hastelloy X and Haynes 230 (both solid solution nickel alloys that are frequently compared to Alloy 617) that do not show any change in the grain size after annealing at temperatures up to $1120^{\circ} \mathrm{C}$ for short times after tensile pre-straining from 1 to $10 \%{ }^{9}$ Given that coarse grains are generally desirable for creep resistance, it is not evident that a change in microstructure resulting from abnormal grain growth would be deleterious to creep-rupture behavior. 


\section{RELAXATION CRACKING}

In addition to the ASME Code considerations with respect to creep-rupture life, there is another degradation phenomenon in austenitic steels and nickel alloys that is frequently referred to as relaxation cracking. Relaxation cracking is a mode of delayed intergranular failure, usually observed in association with welds, that occurs after extended periods of exposure (typically on the order of one to two years) in the range where carbide precipitation occurs and/or the ordered $\gamma^{\prime}\left(\mathrm{Ni}_{3} \mathrm{Al}\right)$ phase forms. This type of cracking is relevant here because it has been observed in cold worked nickel alloys even in the absence of weldments. ${ }^{10}$ For Alloy 617 this phenomenon is most prevalent from 550 to $700^{\circ} \mathrm{C}$. This temperature range is below the anticipated inlet temperature of a VHTR heat exchanger; however, some part of the heat exchanger will certainly operate in this range.

Both Special Metals and VDM Alloy 617 datasheets make specific mention of the susceptibility of the alloy to relaxation cracking. ${ }^{8} \mathrm{VDM}$ notes that the temperature range of susceptibility to cracking is 550 to $780^{\circ} \mathrm{C}$ for solution annealed and welded semi-finished products and 500 to $780^{\circ} \mathrm{C}$ on products which have already seen service and have been repair welded. ${ }^{7}$ Both vendors recommend that components for service in these temperature ranges be given a heat treatment of three hours at $980^{\circ} \mathrm{C}$ to eliminate relaxation cracking even in the solution annealed condition.

In the discussion of allowed cold work for materials currently in Section III subsection NH it was shown that for some exposure times Alloy $800 \mathrm{H}$ is permitted to have between 5 and $20 \%$ cold work as show in Figure NH-4212-1 (reproduced here as Figure 11). It was argued that the limits on Alloy $800 \mathrm{H}$ may be a reasonable surrogate for Alloy 617 since both are solid solution face center cubic alloys. The rules in Section III NH have not been reviewed recently since there has been little high temperature reactor design activity. Note that the temperatures for which exposure is allowed without annealing shown in NH-4212-1 are within the range of relaxation cracking for Alloy $800 \mathrm{H}$ and this issue may need to be reconsidered if Alloy $800 \mathrm{H}$ is to be used for example in a VHTR steam generator.

\section{DISCUSSION}

It is clear that cold work alters the creep rupture behavior of Alloy 617 for strains as low as 5\%. Specific changes to the creep and rupture behavior depend on the amount of cold work and the creep temperature; in general the time and strain to rupture are reduced. The mechanism by which these changes occur is not clear. It does not appear that bulk recrystallization occurs; local recrystallization in the highly deformed region near the fracture surface of ruptured specimens has been reported even in the absence of prior cold work. In any case limiting the fabrication strain to less than $5 \%$ in components which are not given a post-fabrication solution treatment, as required for Alloy $800 \mathrm{H}$ in the current Section III, Subsection NH rules is recommended.

For fabrication strains between 5 and $20 \%$ a post-fabrication solution heat treatment of $1150^{\circ} \mathrm{C}$ for 20 minutes $/ 25 \mathrm{~mm}$ of thickness or 10 minutes, whichever is greater as currently required in ASME Section VIII Division 1 is recommended. This heat treatment will likely recrystallize the material and allow grain growth to relatively large size (larger than ASTM 5) that is required for creep-rupture resistance. Fabrication strains of greater than $20 \%$ are probably not practical due to the high rate of work hardening in Alloy 617 and it does not appear that a limit on total fabrication strain is required.

It is recommended that components that will see service between 500 and $780^{\circ} \mathrm{C}$ be given a heat treatment of three hours at $980^{\circ} \mathrm{C}$ to eliminate relaxation cracking. This recommendation applies regardless of whether the material is in a cold worked or solution annealed condition. Below the $427^{\circ} \mathrm{C}$ temperature limit for low temperature design in Section III of the Code it does not appear that cold work is of concern if the rules of Division 5 pertain. ${ }^{11}$ This part of the Code is specific to high temperature gas 
or sodium cooled reactors and stress corrosion cracking in not expected to be an issue. If Alloy 617 were to be suggested for use under the rules of Section III, division 1, Subsection NB the susceptibility of cold worked Alloy 617 to stress corrosion cracking in water environments would have to be addressed. ${ }^{12}$

\section{CONCLUSIONS}

Cold work alters the creep rupture behavior of Alloy 617 for strains as low as 5\%. Specific changes to the creep and rupture behavior depend on the amount of cold work and the creep temperature; in general the time and strain to rupture are reduced. Current Section III, Subsection NH, rules allow less than 5\% fabrication strain for Alloy $800 \mathrm{H}$ without a post-fabrication solution treatment. It is recommended that the same limit be specified for Alloy 617 to accommodate incidental strains resulting from alignment and final assembly of components using common engineering practice.

For fabrication strains between 5 and $20 \%$ a post-fabrication solution heat treatment of $1150^{\circ} \mathrm{C}$ for 20 minutes $/ 25 \mathrm{~mm}$ of thickness or 10 minutes, whichever is greater, as currently required in ASME Section VIII Division 1 is recommended.

It is recommended that components that will see service between 500 and $780^{\circ} \mathrm{C}$ be given a heat treatment of three hours at $980^{\circ} \mathrm{C}$ to eliminate relaxation cracking. This recommendation obtains regardless of whether the material is in a cold worked, welded, or solution annealed condition.

Below the $427^{\circ} \mathrm{C}$ temperature limit for low temperature design in Section III of the Code it does not appear that cold work is of concern under the rules of Division 5. This part of the Code is specific to high temperature gas or sodium cooled reactors and stress corrosion cracking in not an issue. If Alloy 617 were to be suggested for use under the rules of Section III, Division 1, Subsection NB, the susceptibility of cold worked Alloy 617 to stress corrosion cracking in water environments would have to be addressed.

\section{REFERENCES}

1. J. M. Corum, "Proposed Code Case for Design of Alloy 617 Nuclear Components to Very High Temperatures", ASME Sub-group on Elevated Temperature Design, 1992.

2. S. Chomette, J.-M. Gentzbittel, B. Viguier, "Creep behavior of as-received, aged and cold worked Inconel 617 at 850 and $950^{\circ}$ C", Journal of Nuclear Materials, Vol. 399, 2010, pp. 266-274.

3. Roger H. Cook, "Creep properties of Inconel 617 in air and helium at 800 to $1000^{\circ} \mathrm{C}$ ", Nuclear Technology, vol. 66, 1984, pp. 283-288.

4. ASME Boiler and Pressure Vessel Code, Section III, Rules for Construction of Nuclear Facility Components, Division 1 - Subsection NH, American Society of Mechanical Engineers, New York, 2013.

5. ASME Boiler and Pressure Vessel Code, Section VIII, Division 1, Rules for Construction of Pressure Vessels, American Society of Mechanical Engineers, New York, 2013.

6. Special Metals Fabricating Guide, Special Metals Corp., Huntington, WV, 2008.

7. Nicrofer 5520 Co - Alloy 617 Material Data Sheet, ThyssenKrupp VDM, Datasheet 4019, 2005.

8. INCONEL Alloy 617 Data Sheet, Special Metals Corp., Publication No. SMC-029 Huntington, WV, 2005. 
9. Fabrication of Haynes and Hastelloy Solid-Solution Strengthened High-Temperature Alloys, Haynes International, Kokomo, IN, 2002.

10. J. C. van Wortel, "Relaxation cracking in the process industry, an underestimated problem", unpublished industry working group report (shared with ASME) 1998.

11. ASME Boiler and Pressure Vessel Code, Section III, Rules for Construction of Nuclear Facility Components, Division 5 - High Temperature Reactors, American Society of Mechanical Engineers, New York, 2013.

12. ASME Boiler and Pressure Vessel Code, Section III, Rules for Construction of Nuclear Facility Components, Division 1 - Subsection NB, American Society of Mechanical Engineers, New York, 2013. 